\title{
USING CONTRACTS TO ANALYZE INFORMAL FINANCE
}

\author{
by
}

Dale W Adams

October 19, 1992

(Revised Version)

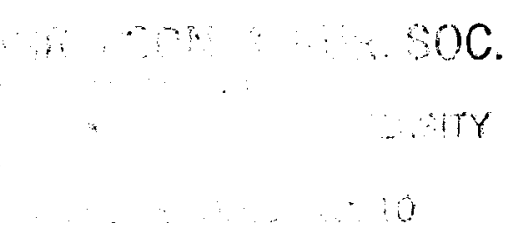

Rural Finance Program

Department of Agricultural Economics and

Rural Sociology

The Ohio State University

2120 Fyffe Road

Columbus, Ohio 43210-1099 



\section{USING CONTRACTS TO \\ ANALYZE INFORMAL FINANCE}

by

Dale W Adams

The principal problem in understanding the actions of men is to understand how they think--how their minds work.

--P. W. Bridgman. Reflections of a Physicist.

\section{INTRODUCTION}

For centuries discussions about informal finance have been filled with confusion and controversy (Nelson). ${ }^{1}$ Moralists condemn it, politicians attempt to control and regulate it, sociologists debate its usefulness, economists dissect it looking for imperfections--while, billions of people voluntarily participate in it. Fashioning a composite picture of informal finance is similar to summing the disjointed reports of judgmental blind people who have independently felt an elephant's appendage; the parts depicted do not add to a coherent whole.

\footnotetext{
${ }^{1}$ Formal finance is here defined as those financial contracts that are sanctioned and supervised by government organizations, such as central banks, ministries of finance, or superintendents of banks. Semi-formal finance is provided by entities that operate under government charter but transact financial contracts with little or no government supervision. Informal finance encompasses all other financial lending and deposit taking that occurs outside government sanction or supervision, aside from general rules that apply to fulfilling contracts.
} 
This confusion justifies looking for new ways of analyzing informal finance, ways that do not prejudge the virtue of the activities and people involved, that employ common units of analysis, and that also apply research techniques representing the manner in which people make decisions. I propose using contracts as a framework for such analysis. Because of my professional interests I stress their economic aspects.

\section{BACKGROUND ON CONTRACTS}

The use of contracts in economic analysis germinated in institutional economics and later blossomed in the study of labor arrangements (Commons; Rosen). Interest in contracts has reemerged recently in new institutional economics where transaction costs are emphasized (Williamson), in principal agent analysis (Ross), and in the study of asymmetric information (Akerloff). Literature on this topic has expanded to include implicit contracts (Rosen), incomplete contracts (Hart and Holmstrom), and incentive contracts (Cheung). The analysis has also been extended to include studies of land tenure and credit (Braverman and Stiglitz; Stiglitz and Weiss).

Contracts can be used to describe multifaceted agreements between individuals or

firms. They may involve explicit as well as implicit stipulations, they may be written or oral, and they may include few or many elements (Mahoney). Formal financial contracts are often written and contain mostly explicit stipulations, while their informal counterparts tend more often to be oral and involve implicit elements. Some contracts can be enforced in courts of law, while others are enforceable only through social sanctions (Galanter). In the 
discussion that follows I argue for thinking of contracts as being the products that are made and handled by financial intermediation, particularly in informal finance.

In neoclassical economics transactions between individuals are assumed to occur under simple terms; in a cash transaction the vendor contracts to sell a certain amount of a good at a price to the buyer and the exchange takes place quickly. Economists usually ignore that a contract is involved in these exchanges because the terms are implied rather than written, the transaction is impersonal and takes place instantaneously, and the contract is enforced by general norms of the society. Sellers break these contracts if they fail to give the buyer the good or service upon receiving payment, and buyers likewise break contracts if they appropriate goods or services without paying for them. Failing to fulfill these simple and short-term contracts is stealing in every society.

Contracts are a more robust notion where transactions involve intertemporal stipulations--receive now, but pay later--and where risk, uncertainty, and insurance are significant considerations. Contracts that govern such transactions typically involve many more stipulations than do instantaneous, cash arrangements. Considerations of time and risk are universal components of financial contracts.

\section{STIPULATIONS IN FINANCIAL CONTRACTS}

Those of us who study informal finance are often amazed at the rich variety of arrangements we encounter in most countries. Sociologists and anthropologists have feasted on describing the enormous variety of these arrangements (e.g., Bouman; Firth and Yamey). Applying the analogy of clothing to contracts, informal finance is able to tailor contracts to 
fit the individual dimensions, requirements, and tastes of a wide spectrum of lenders and borrowers. Stipulations in each contract can be adjusted to fit the idiosyncratic needs and desires of the parties involved. In contrast, formal finance processes contracts that are more standardized and less individually tailored. Formal intermediaries require borrowers and depositors to "wear" contracts that are largely pre-made.

Participants are able to form nearly limitless combinations of terms and conditions-both explicit and implied--in financial contracts. At least eight types of stipulations can be identified with many permutations in each type. These include the amount of the loan, the term of the loan, how and when the loan is to be repaid, the interest payment involved, loan guarantees or collateral requirements, how loan transaction costs are shared, other explicit linked arrangements, and additional implied arrangements that are linked to the loan.

\section{$\underline{\text { Loan size }}$}

The amount of money involved is typically the most prominent stipulation in loan contracts. If the loan and its repayment are in cash, the size of loan is denominated in money. If at least one side of the loan transaction is denominated in units of goods or services, the loan valuation problem is less straight forward. For obvious reasons, both borrower and lender generally avoid spending much time negotiating the terms and conditions of small loans but typically expend more time on large loans. Likewise, contracts that deal with small loans usually involve fewer stipulations than those processing large amounts. Term of loan

The period or term over which the agreement is in effect is another important contract element. It is common for lenders and borrowers to spend more time negotiating 
a long-term loan and including a larger number of stipulations than they would in crafting a short-term contract. Both the lender and borrower see a loan for only a month as being quite different from an equal-sized loan for 12 months, for example. A sequence of 12 onemonth loans for 100 units of money would be of the same economic magnitude as a single 12-month loan of 100 units of money, aside from the differences in transaction costs involved.

Especially in informal finance, not all loan contracts specify when the loan is to be fully repaid--some contracts are incomplete or open-ended. An individual may borrow money from a relative, for example, with the implicit understanding that the loan will be repaid when the borrower is able to do so. These open-ended arrangements may be renegotiated and amended later when a specific time for repaying the loan is appended to the contract. In still other cases there may be an implicit understanding between borrower and lender that the time period of the loan can be renegotiated under certain conditions.

\section{Loan repayment}

Aside from loans among friends and relatives, most financial contracts include specifications about what form and when loan repayments are to be made. The loan may be transacted in cash or kind with repayment specifications calling for money, products, or 
even services. $^{2}$ If both sides of the transaction are done in kind there is no finance involved, although a barter loan is made. ${ }^{3}$

Lenders and borrowers also have ample latitude in the specification of loan repayments. Some contracts require that the entire amount of the loan plus interest is due in one lump-sum payment at the end of the contract period. For both the lender and the borrower this pattern of loan repayment is quite different from one that specifies $1 / 52$ nd of the loan be repaid each week for a year. In the first case the borrower has effective use of the entire amount of the loan for a full 12 months, while in the second case the borrower has effective use of only half the total value of the loan for the full 12 months.

A number of additional repayment patterns are found both in formal and informal financial contracts. Adjustments in these patterns have a major impact on the perceived worth of the contract. Loans, for example, that require rice farmers to make daily payments for fertilizer bought on credit would usually result in a mismatch with their cash flows and, thus, would be viewed as an undesirable contract by borrowers. Similar repayment terms on loans made to individuals who sell commodities daily in central markets, however, might be viewed as satisfactory arrangements by both lender and borrower.

\footnotetext{
${ }^{2}$ Loans that are made and repaid in cash, loans that are made and repaid partly in cash and partly in kind, and various barter arrangements are often partial substitutes. Two farmers may decide to lend and borrow labor from each other through a labor sharing relationship, for example, instead of borrowing money to pay for purchased labor. In the same sense, crop-sharing arrangements are also substitutes for cash loans.

${ }^{3}$ The main distinction between a loan that involves only barter and a loan that involves cash is the additional risk and uncertainty that changes in the purchasing power of money pose for financial transactions.
} 


\section{Interest rates}

Understandably, the lender's compensation for making loans and the payments borrowers must make for the privilege of borrowing are also important specifications in loan contracts. Both lender and borrower interpret a loan that carries an interest rate of 1 percent per month as being something quite different from one that carries rates of 10 percent per month. There is a large variety of interest rate options. These include simple interest, compounded interest, interest payments that are discounted in advance, add-on interest, and level payments pegged to the initial amount of the loan. The clarification of interest specifications is further complicated by various types of interest rates, such as nominal rates that ignore changes in overall price levels, real rates of interest that reflect adjustments for price changes, hidden interest charges, and effective rates that take into consideration interest paid, compared to principal outstanding.

The payments made for loans, especially in Islamic countries, may avoid using explicit interest by calling the payments dividends, mark ups, or shared profits from jointly financed operations.

\section{Loan guarantees and sanctions}

Other important specifications in financial contracts are the guarantee or collateral involved and the types of sanctions that might be applied in case of default. A loan that involves a hand shake as a guarantee is something quite different from one that requires pledging collateral worth several times the value of the loan. In some cases the borrower may lose the use rights of the collateral pledged through pawning. This may include borrowing from a pawnshop in Sri Lanka, pawning use of cocoa trees in Ghana, or pawning 
paddy land in Thailand. In other cases contracts involve mortgages that place a lean against pledged property but allow the borrower to continue to use pledged assets. In still other cases, third parties, including groups, may be asked to guarantee all or part of a loan.

Implied guarantees and informal sanctions are prominent in informal finance. Borrowers may strive to repay loans from sources they view as providing high quality and dependable services. In contrast, they may assign less priority to repaying loans made by government-owned agricultural development banks that provide undependable and low quality services. The denial of access to future loans is a more powerful informal sanction for the first type of lender than for the second.

Each time borrowers take loans they essentially pledge their creditworthiness in the loan contract. Borrowers who default forfeit their creditworthiness, at least in the judgement of lenders who suffer the default. In the small and highly personalized societies that typify the life of poor people in most low-income countries, a failure to repay one lender can result in an individual losing most borrowing privileges. The ability of the lender to exercise a range of informal sanctions--including extra-legal force--is an important aspect of informality.

The provision of loan guarantees may impose costs on both borrowers and lenders. This includes the expenses involved in obtaining documents needed to mortgage property or gifts and payments made to individuals who co-sign loan contracts. In self-help groups members may be required to attend periodic meetings that impose opportunity costs on them as a way of forming mutual trust that substitutes for more tangible loan collateral. 
Cumbersome legal procedures in some countries make it costly--sometimes virtually impossible--for lenders to legally retrieve assets pledged as collateral on defaulted loans. Under these circumstances lenders compensate by physical force to access collateral, or adjust other stipulations in loan contracts to offset judicial shortcomings. ${ }^{4}$

\section{Distribution of loan transaction costs}

Transaction costs are important features in many loans and they affect behavior of both lender and borrower. These costs may be either implicit or explicit. One lending procedure may impose relatively high loan transaction costs on borrowers, while another procedure might result in lenders absorbing most of these costs. In general, informal finance is transacted in clients' homes, their place of work, their neighborhoods, or where they shop. In contrast formal financial transactions usually occur on the premises of the financial intermediary--the client is forced to come to the bank.

The distribution of these costs among the participants is an important stipulation in financial contracts. Peddlers who sell items on credit door-to-door in rural areas of the Philippines, for example, may stipulate they will deliver merchandise and then return daily or weekly to collect loan payments, thus absorbing most transaction costs. In contrast, individuals in Guatemala who live far from town may be forced to visit a bank six or seven times to negotiate loans, to receive disbursements, and then to repay their loans. Such procedures result in borrowers incurring substantial transportation costs and lost-work time, while lenders have relatively little cost in effecting the loan. Likewise, farmers in Uganda

${ }^{4}$ In a few countries governments have gone to the extreme of passing debt-relief legislation that nullifies informal loan contracts. 
may wish to make deposits in distant banks but can only do so by incurring substantial transaction costs, in the form of lost work time and transportation costs, that are much larger than those experienced by deposit takers.

Economists usually assume that interest payments are borrowers' costs of acquiring loans and that interest receipts are the benefit realized by lenders. This only holds, however, if there is no friction in the exchange in the form of transaction costs and if nothing else of worth accompanies the loan transaction. It is unlikely, for example, that rural peddlers who sell on credit in the Philippines or their clients make economic decisions solely on the basis of interest payments, particularly the borrowers. They are more likely to make these lending/borrowing decisions on the basis of total lending and borrowing costs, only part of which is comprised of interest payments.

\section{Tied transactions}

Many informal financial transactions are explicitly linked to the sale or purchase of inputs, products, or consumption goods. A farmer in Zaire may extend loans to workers as part of a labor-credit contract; a trader in Nepal may make advanced payments to rice farmers as part of a product-purchase agreement; farmers in Jamaica may give their products to peddlers on consignment for sale and agree to wait for later payment; a merchant in Egypt may sell chemical fertilizer to farmers on credit as a way of boosting sales; and a store owner in North East Brazil may allow customers to buy consumer items on credit. Offering credit is a device used by many merchants and traders to promote their main business activity--a way of competing. Explicit tying of these activities is, therefore, an important specification in associated loan contracts. 
These explicit-tied arrangements include a number of variants. Some loans may involve no interest payment, but require sellers to accept concessionary prices for their products or services, or for buyers to pay above-market prices for products or services. In other cases, where one side of the financial transaction involves physical goods, specifications in contracts may require one of the parties to absorb the risk of product price change. In still other cases, the contract may involve other side-agreements that benefit or cost either borrowers or lenders. For example, the ijon system in Indonesia and the dadon system in Bangladesh involve traders making forward payments for rice crops before they are harvested, and in doing so agreeing to absorb harvesting costs and price change risks (Ghate; Partadireja).

Implicit stipulations

Many informal loans are embedded in multifaceted relationships that implicitly tie other activities to lending. These implicit stipulations are as varied as are relationships among people. The lender and borrower, for example, may feel obligated to attend social club meetings in Vietnam or South Africa to reinforce their relationships (Barton; Lukhele). Members of informal savings clubs among Korean or Mexican immigrants in Southern California may participate in these groups because they build mutual trust and possibilities of borrowing or doing business both within and outside the group (Light, Kwuon and Zhong; Velez-Ibanez). Individuals in all countries may lend to friends or relatives with the unstated understanding that loans will be reciprocated should the need arise in the future (Platteau and Abraham). 
In still other cases, such as in Colombia and Peru lenders may have patronal relationships with their borrowers. This may include implicit understandings that the patron will intercede for the borrower in legal matters and in disputes with authorities. These implicit agreements in countries such as Niger may extent to the provision of loans in times of personal emergencies, to holding some of the borrower's funds for safe keeping, and to provision of food in times of disaster (Cuevas and Graham). In many cases, informal borrowinglending is only one of a number of interlaced activities that strengthen interpersonal relationships, facilitate exchange, and allow individuals to survive in uncertain environments (Mahoney).

\section{TRADE OFFS AMONG SPECIFICATIONS}

Lenders who craft loan contracts not only have a variety of specifications they can choose from, but they also have latitude for substituting one element in a contract for another. For example, one contract may have a low interest rate but involve procedures that transfer most loan transaction costs to borrowers; at the same time another contract may include high interest rates but impose few additional costs on borrowers. The same lender may also offer other contracts that contain moderate interest rates, more loan collateral, and a sharing of loan transaction costs between lender and borrower.

Prudent lenders adjust loan specifications to the perceived creditworthiness of borrowers and to prevailing risks and uncertainties. An individual with a bad reputation will not be able to negotiate the same loan contract that a distinguished person might expect. Likewise, a new client will generally be offered a loan with specifications that are substan- 
tially different from a client who has previously dealt with the lender. Analogous contact distinctions will be made between borrowers who operate farms in drought prone areas compared to borrowers who have access to dependable irrigation. Similarly, those who wish to borrow large amounts for extended periods of time likely negotiate loan contracts that are quite different from individuals who request small loans for only several days. This differentiation of contracts is found in informal rotating savings credit associations in countries such as The Gambia, Mozambique, and Cameroon where new group members may be required to wait until late in the rotation cycle to receive their share of the funds.

From the borrowers perspective, they may be willing to substitute relatively high interest rates for associated transaction costs that are modest and for linked implied agreements that the lender will provide additional loans in times of emergency--offering a credit reserve. Or, borrowers may be only willing to incur substantial transaction costs to secure a loan if the interest charge is modest and other tied services are viewed as desirable.

\section{PRODUCTS AND PRICES}

In the foregoing I argued that borrowers and lenders base their financial decisions on multifaceted contracts and that loan size and interest rates are only two of a number of specifications that are included in these financial products. For some people the interest payment may be a relatively minor consideration compared to other elements in the contract, especially when loans are small and for short periods of time. Unfortunately, when economists apply their tools to interpreting differences in interest rates across financial markets, both formal and informal, they usually ignore these other specifications. Some 
economist employ a morality model to "prove" exploitation exists in informal finance and cite differences in interest rates on loans made by formal and informal sources as proof of monopoly powers (e.g., Bhaduri; Sarap). Other economists employ an economic efficiency model and cite differences in interest rates on loans as signs of fragmented financial markets that are inefficient in allocating funds among economic alternatives (e.g., Bardhan; McKinnon).

I have reservations about using either the morality or the efficiency model to analyze informal finance. My first reservations is that interest rates often do not represent all of the perceived costs or benefits of either extending or obtaining loans. Second, in my opinion, it is an error to think of informal financial systems as producing homogeneous contracts. Instead, one might better think of heterogeneous contracts as being the norm of what is produced, especially in informal finance.

What is the product?

In making judgements about the morality or efficiency of financial market activities it is vital to compare like with like. No one would argue a market was defective or abusive that assigned a lower price on a badly bruised, small apple than on a large, crisp and attractive apple. Virtually everyone would agree that these are two different products in the eyes of consumers, despite the fact that both fruits belong to the apple species.

Part of the problem with both the morality and efficiency models lies in the definition of the product or service--the apples-oranges issue. One should not expect the price that a consumer is willing to pay for two goods to be the same unless, in the opinion of the buyer, the two goods provide equal utility: both apples are identical in quality and size, or 
both oranges are similarly identical. The fact that a consumer is willing to pay a higher price for one fruit compared to the other based on perceived quality differences, says nothing about the structure of the apple and orange markets, that is, whether or not they involve monopoly power.

A difference in price between two goods is not prima facie evidence proving the price of the more expensive good includes monopoly rents. These differences in prices may only reflect the additional satisfaction consumers expect to realize from one fruit compared to the other. Without additional information on the structure of the markets for apples and for oranges an economist can only deduce something about the ordinal preferences of consumers from such price information. We can only deduce that something is askew in the market for apples if at the same time and place two identical apples are sold for different prices: for example, a poor person paying a higher price than a rich person for identical apples. Perhaps we should apply the same logic to analyzing loans and in doing so, we must be careful to compare prices among contracts that are similar.

\section{Price of A Loan?}

Most economists think of price as an indication of the sacrifice people incur when they purchase a good. This notion of price is often equated with interest payments when economists make judgements about financial transactions. If contracts are the products handled by financial intermediation, it is not at all clear that the interest payments specified in the contract captures a major part of the sacrifice or benefit borrowers and lenders realize from the transaction, particularly in informal finance. Respective transaction costs increase the sacrifice incurred by borrowers and reduce the net benefits realized by lenders. 
Likewise, other specifications in the agreement may increase or decrease the perceived benefits or costs associated with the contract. Generally, the smaller and shorter the term of the loan, the less important is interest payment in influencing the behavior of participants in loan contracts.

As a minimum, interpreters of informal finance should focus on borrowing costs-interest payments plus loan transaction costs--as determinants of loan demand. Since these transaction costs may not vary much with loan size, the borrowing costs are particularly important when evaluating loans that are small and for short term--the types of loans that are the bread-and-butter of informal finance.

In most informal financial transactions interest payments are only part of the cost or benefit that borrowers and lenders experience. Economists error when they think of interest payments as being prices of loans and the only determinants of loan demand. We further error when we ignore the tremendous diversity in lending and associated arrangements and think of only the amount of money as being the "product" demanded.

\section{CONTRASTING CONTRACTS}

A brief description of two quite different loan contracts in a Latin American country may help to clarify my arguments. Variants of the first contract are commonly offered to urban street peddlers in this country. The second contract is one that a defunct agricultural bank often offered to operators of small- and medium-sized farms. 


\section{Peddler loans}

Street peddlers occasionally run short on liquidity to buy inventory such as cigarettes, candy bars, gum, and other impulse purchase items. A number of wholesalers in central markets provide these items on credit in the morning with repayment due by the next day. The average loan is only for the equivalent of \$10US, the average term is for 24 hours or less, and a single repayment of \$11US is specified. The typical interest charge is thus 10 percent--an annualized rate of 3,650 percent. The loans are made with no physical collateral, but borrowers understand that the "word will get around" and that they will likely lose access to most informal loans if they should default. Because these lenders operate in central markets, close to where street peddlers operate, the lender absorbs virtually all loan transaction and collection costs.

While lenders understandably tie loans to the purchase of their goods, they also share valuable business information with borrowers about what goods are selling well or poorly and also give their most valued clients first access to new goods. Loan agreements are flexible and most clients are able to renegotiate delays in loan repayment and may also ask wholesalers for other emergency loans. In some cases the lender may intercede as character witnesses when clients have difficulties with police. Overall, borrowers value their dependable and flexible relationships with these wholesalers, loan recovery rates are high, and there are few complaints among borrowers about lender behavior.

\section{Agricultural bank loans}

Until its demise the government owned Agricultural Bank provided small loans with the following characteristics: loan size was about $\$ 300 \mathrm{US}$, a single payment at the end of six 
months was required, and interest was 1 percent per month. Borrowers were often required to provide loan collateral in the form of a mortgage against property worth several times the value of the loan and most loan contracts also required co-signers. Procedures forced borrowers to visit the bank's urban office an average of five or six times to satisfy collateral requirements, fill out papers needed to request the loan, gain final approval of the loan, receive several loan disbursements, and finally to repay the loan.

Unlike some informal lenders, the agricultural bank did not tie its loans to purchase of other goods or services, did not provide useful business information or advice to borrowers, and also did not make emergency loans on the spur of the moment. One did not have to interview many borrowers from the bank to hear grumbling about the quality of service, requests for bribes, the amount of paperwork, and late loan approval and disbursements. The ultimate demise of the Bank also proved it was not a durable or dependable source of financial services.

There are few similarities among the stipulations written into peddler loans and the stipulations included in loan contracts issued by the Agricultural Bank. In terms of products, about the only thing they have in common is that they are both called loans. A huge variety of other loan contracts can be found in this country with specifications that lie between these two extreme examples.

\section{CONCLUSIONS}

Discussions about informal finance have been long on value judgements and horror stories and short on careful analysis. Applying the notion of contracts to informal financial activities may allow social scientists to clear away some of the fog that currently surrounds 
this topic. It may also allow economists, sociologists, and anthropologists to integrate more of their work in this topic. Even more importantly, contracts may allow us to organize information in a manner that more closely resembles the way people actually make decisions about their participation in financial activities, both informal and informal. 


\section{REFERENCES}

Akerlof, G. "The Market for Lemons." Quarterly Journal of Economics 84(1970):488-500.

Bardhan, P. "Interlocked Factor Markets and Agrarian Development: A Review of Issues." Oxford Economic Papers 32(1980):82-93.

Bhaduri, A. The Economic Structure of Backward Agriculture. New York: Academic Press, 1983.

Bouman, F.J.A. Small, Short and Unsecured: Informal Rural Finance in India. Delhi, India: Oxford University Press, 1989.

Braverman, A. and J.E. Stiglitz. "Sharecropping and The Interlinking of Agrarian Markets." American Economic Review 72(1982):695-715.

Bridgman, P.W. Reflections of a Physicist, 2nd edition. New York: Philosophical Library, 1955.

Cheung, S.N.S. The Theory of Share Tenancy: With Special Application to Asian Agriculture and The First Phase of Taiwan Land Reform. Chicago: University of Chicago Press, 1969.

Commons, John R. Legal Foundations of Capitalism. Madison, Wisconsin: University of Wisconsin Press, 1924.

Cuevas, Carlos E. and Douglas H. Graham. "Informal Finance and Financial Market Integration in El Salvador." Economics and Sociology Occasional Paper No. 1933, Department of Agricultural Economics and Rural Sociology, The Ohio State University, February, 1992.

Firth, Raymond and B.S. Yamey. Capital, Saving \& Credit in Peasant Societies. Chicago: Aldine Publishing Company, 1964.

Galanter, Marc. "Justice in Many Rooms: Courts, Private Ordering, and Indigenous Law." Journal of Legal Pluralism 19(1981):1-47.

Ghate, P. B. Informal Finance: Some Findings from Asia. Hong Kong: Oxford University Press, 1992

Graham, Douglas H. and others (eds.). "A Review of formal and Informal Finance in The Gambia, 1981-91: Markets, Institutions, Programs, and Policies." Unpublished report prepared for the Agency for International Development in The Gambia, Department 
of Agricultural Economics and Rural Sociology, The Ohio State University, September, 1992.

Hart, Oliver and B. Holmstrom. "The Theory of Contracts." In Advances in Economic Theory. Fifth World Congress, edited by T. Bewley, Cambridge: Cambridge University Press, 1987.

Light, Ivan, Im Jung Kwuon and Deng Zhong. "Korean Rotating Credit Associations in Los Angeles." Amerasia 16(1990):35-54.

Lukhele, Andrew Khehla. Stokvels in South Africa: Informal Savings Schemes. Johannesburg, South Africa: B1 Community, Amagi Books, 1990.

Mahoney, Nicholas. "Contract and Neighborly Exchange among the Birwa of Botswana." Journal of African Law 21(1977):40-65.

McKinnon, Ronald I. Money \& Capital in Economic Development. Washington, D.C.: The Brookings Institution, 1973.

Nelson, Benjamin N. The Idea of Usury: From Tribal Brotherhood to Universal Otherhood. Princeton, New Jersey: Princeton University Press, 1949.

Partadireja, Ace. "Rural Credit: The Ijon System." Bulletin of Indonesian Economic Studies 10(1974):54-71.

Platteau, Jean-Philippe and Anita Abraham. "An Inquiry into Quasi-Credit Contracts: The Role of Reciprocal Credit and Interlinked Deals in Small-Scale Fishing Communities." Journal of Development Studies 23(1987):461-490

Rosen, Sherwin. "Implicit Contracts: A Survey." Journal of Economic Literature 23(1985):1144-1175.

Ross, S. "The Economic Theory of Agency: The Principal's Problem." American Economic Review 63(1973):134-139.

Sarap, Kailas. "Interest Rates in Backward Agriculture: The Role of Economic and ExtraEconomic Control." Cambridge Journal of Economics 14(1990):93-108.

Stiglitz, J.E. and A. Weiss. "Credit Rationing in Markets with Imperfect Information." American Economic Review 73(1981):393-410.

Velez-Ibanez, Carlos G. Bonds of Mutual Trust: The Cultural Systems of Rotating Credit Association among Urban Mexicans and Chicanos. New Brunswick, New Jersey: Rutgers University Press, 1983. 
Williamson, Oliver E. The Economic Institutions of Capitalism. New York: The Free Press, 1985. 


\section{$\cdots$}




$$
\text { … }
$$

